\title{
Quantifying Batrachochytrium dendrobatidis and Batrachochytrium salamandrivorans Viability
}

\author{
Alexa Lindauer, ${ }^{1}$ Tiffany May, ${ }^{1}$ Gabriela Rios-Sotelo, ${ }^{1}$ Ciara Sheets, ${ }^{1}$ and Jamie Voyles ${ }^{1}$
}

${ }^{1}$ Department of Biology, University of Nevada, Reno, 1664 North Virginia Street, Reno, NV 89557

\begin{abstract}
The disease chytridiomycosis is responsible for global amphibian declines. Chytridiomycosis is caused by Batrachochytrium dendrobatidis $(B d)$ and B. salamandrivorans (Bsal), fungal pathogens with stationary and transmissible life stages. Establishing methods that quantify growth and survival of both life stages can facilitate research on the pathophysiology and disease ecology of these pathogens. We tested the efficacy of the MTT assay, a colorimetric test of cell viability, and found it to be a reliable method for quantifying the viability of $B d$ and $B s a l$ stationary life stages. This method can provide insights into these pathogens' growth and reproduction to improve our understanding of chytridiomycosis.
\end{abstract}

Keywords: Batrachochytrium dendrobatidis, Batrachochytrium salamandrivorans, MTT assay, Pathogen, Disease, Amphibian declines

Chytridiomycosis is an amphibian disease caused by the fungal pathogens Batrachochytrium dendrobatidis $(B d)$ and B. salamandrivorans (Bsal; Berger et al. 1998; Longcore et al. 1999; Martel et al. 2013). Both pathogens have caused amphibian declines and are considered threats to biodiversity (Skerratt et al. 2007; Wake and Vredenburg 2008; Stegen et al. 2017). Although the pathogenesis of Bsal is less understood (Van Rooij et al. 2015), development of lethal chytridiomycosis from $B d$ has been linked with increases in infection intensity (i.e., $B d$ loads; Voyles et al. 2009; Vredenburg et al. 2010). As such, investigations on $B d$ and Bsal growth have been key to understanding the biology of this disease (Woodhams et al. 2008; Voyles et al. 2017).

Both $B d$ and Bsal have complex life histories (Longcore et al. 1999; Martel et al. 2013). Motile Bd and Bsal zoos-

Published online: May 23, 2019

Correspondence to: Jamie Voyles, e-mail: jvoyles@unr.edu pores encyst and develop into zoosporangia. Stationary zoosporangia produce zoospores and release them into the environment or back onto the host (Longcore et al. 1999; Berger et al. 2005; Martel et al. 2013). Since increases in zoospore production are not always proportional to increases in zoosporangia growth rate (e.g., at temperatures below the $B d$ thermal optimum; Woodhams et al. 2008; Voyles et al. 2012), understanding differences in growth and reproduction of specific life stages is important to understand the infectivity of these pathogens and the tradeoffs they face under different conditions.

Multiple methods have been used to measure $B d$ and Bsal growth in vitro (Piotrowski et al. 2004; Martel et al. 2013). Zoospore production can be measured by counting motile zoospores using a hemocytometer, and stains (e.g., trypan blue, SYBR-14, propidium iodide) can improve count accuracy (Stockell et al. 2010; McMahon and Rohr 2014). Lag, exponential, and stationary phases of $B d$ and 
Bsal growth can be measured by reading optical density (OD) at $490 \mathrm{~nm}$ (Rollins-Smith et al. 2002, Piotrowski et al. 2004; Rollins-Smith et al. 2006). However, OD measurements lack specificity because they do not differentiate between living and dead cells.

We tested the efficacy of an MTT assay in measuring $B d$ and Bsal growth and viability. The MTT assay is a reliable colorimetric test for cell viability that has been used in unicellular fungi and mammalian cell lines (Levitz and Diamond 1985; Freimoser et al. 1999). MTT (3-(4,5dimethylthiazol-2-yl)-2,5-diphenyltetrazolium bromide) is a yellow tetrazolium salt that is reduced to purple MTTformazan crystals in metabolically active cells (Mosmann 1983; Liu et al. 1997). The color change can be quantified by solubilizing the formazan crystals and reading culture absorbance at $570 \mathrm{~nm}$, the most sensitive wavelength for this assay (Altman 1976).

We conducted experiments to (1) optimize MTT concentration and incubation time for $B d$, (2) test the efficacy of the assay using serial dilution, and (3) apply the assay to quantify $B d$ and $B s a l$ growth and viability over time. In addition, we measured zoospore production and zoosporangia growth by counting zoospores and reading $\mathrm{OD}_{490}$ to relate the MTT assay to other accepted quantification methods.

We revived $B d$ and $B s a l$ isolates ( $B d$ MYLF-16343, $B d$ NMBF-04, Bsal AMFP13/1) from cryopreservation (Boyle et al. 2003) and passaged them following established protocols (Longcore et al. 1999; Martel et al. 2013). Specifically, we cultured the pathogens in TGhL media in tissue culture flasks at $18^{\circ} \mathrm{C}$ for $7-9$ days for $B d$ and at $10^{\circ} \mathrm{C}$ for 3-4 days for Bsal until we observed zoospore release. We then harvested zoospores by scraping cells from the flasks and filtering cultures through sterilized filter paper to remove zoosporangia and debris (Voyles 2011). We inoculated $100 \mu \mathrm{L}$ diluted zoospore filtrate into 96-well plates (Bd concentration: $23 \times 10^{4}$ zoospores $/ \mathrm{mL}$; Bsal concentration: $48 \times 10^{4}$ zoospores $/ \mathrm{mL}$ ) and used heat-killed zoospore filtrate, heat-killed for $10 \mathrm{~min}$ in a $40^{\circ} \mathrm{C}$ water bath, as a negative control. We incubated the plates at temperatures within the pathogens' optimal ranges $(B d$ : $17.5^{\circ} \mathrm{C}$, Bsal: $10^{\circ} \mathrm{C}$; Piotrowski et al. 2004; Martel et al. 2013).

To determine an optimum MTT concentration and incubation time, we added either $10 \mu \mathrm{L}$ or $20 \mu \mathrm{L} 5 \mathrm{mg} / \mathrm{mL}$ MTT in sterile PBS to $100 \mu \mathrm{L} B d$ culture and stopped the reaction after 30-min, 1-h, 2-h, or 24-h incubation (Mosmann 1983; Hansen et al. 1989). At each time point, we solubilized the formazan crystals by adding $140 \mu \mathrm{L}$ sodium dodecyl sulfate in dimethylformamide solution (20\% SDS/ $50 \%$ DMF w/v) and homogenizing gently (Hansen et al. 1989). We then measured OD at $570 \mathrm{~nm}$ (Biotek ELx800 Absorbance Reader). We fit asymptotic regression curves using the "nlme" package (Pinheiro et al. 2018) in R v3.4.3 (used for all analyses; R Core Team 2018). We corrected OD values by subtracting mean heat-killed OD from live well readings and compared incubation times and concentrations using $t$ tests.

To test the efficacy of the MTT assay, we conducted a serial dilution experiment and measured $B d$ viability on the day of peak zoospore production. We inoculated $100 \mu \mathrm{L}$ actively growing culture into sterile flat-bottom 96-well plates as described above and serially diluted the cultures in $50 \mu \mathrm{L}$ TGhL media. We repeated the same dilution with heat-killed cultures as a negative control. We added $20 \mu \mathrm{L}$ $5 \mathrm{mg} / \mathrm{mL}$ MTT, incubated for $2 \mathrm{~h}$, solubilized the formazan product, and recorded OD at $570 \mathrm{~nm}$. We fit a linear model to corrected $\mathrm{OD}_{570}$ to determine whether the MTT colorimetric signal was directly proportional to cell density.

To determine the viability of $B d$ and Bsal cultures over time, we used the MTT assay to quantify culture growth every other day for 12 days. On each sampling day, we used the optimized MTT assay (as described above) to measure viability in randomly selected wells. To compare the MTT assay to widely accepted methods for measuring $B d$ and $B s a l$ growth and reproduction, we measured $\mathrm{OD}_{490}$ before initiating the MTT assay, and we quantified zoospore production using a hemocytometer. For $B d$ cultures, we compared OD with and without the addition of MTT over time using ANCOVA.

We found that MTT effectively stains $B d$ and Bsal, visibly staining viable zoosporangia purple. Asymptotic regression models $(P<0.001$ for all parameters of both concentrations) show that $\mathrm{OD}_{570}$ readings of MTT-assayed cultures increased over $24 \mathrm{~h}$, reached an asymptote after $4 \mathrm{~h}$, and differed by MTT concentration (Fig. 1). For wells exposed to $20 \mu \mathrm{L} 5 \mathrm{mg} / \mathrm{mL}$ MTT, we did not detect a significant difference between $\mathrm{OD}_{570}$ readings at 2 and $24 \mathrm{~h}$ ( $t$ test, $\left.t_{(8)}=-1.84, P=0.10\right)$. Wells incubated with $20 \mu \mathrm{L} 5 \mathrm{mg} / \mathrm{mL}$ MTT had higher $\mathrm{OD}_{570}$ readings than wells incubated with $10 \mu \mathrm{L} 5 \mathrm{mg} / \mathrm{mL}$ MTT ( $2 \mathrm{~h}: t_{(8)}=-4.2687$, $P=0.003 ; 24$ h: $\left.t_{(8)}=-4.1104, P=0.003\right)$. We did not observe a reduction of MTT in purified zoospores on day 0 for either pathogen at these MTT concentrations.

We found that OD readings of the MTT assay are directly proportional to $B d$ density (Fig. 2). OD readings 


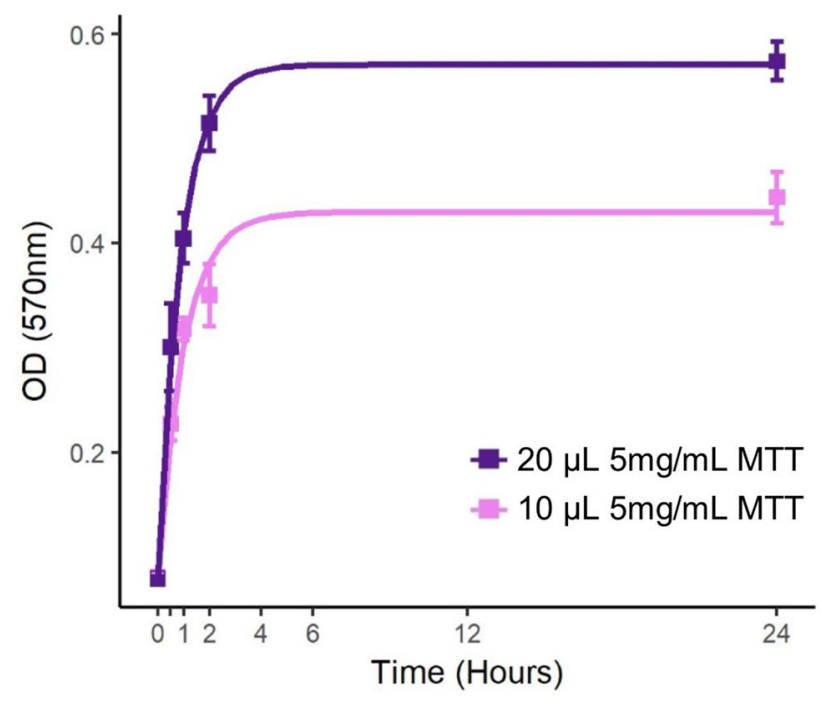

Figure 1. A comparison of optical density (OD) measurements at multiple incubation time points and two different concentrations of MTT (3-(4,5-dimethylthiazol-2-yl)-2,5-diphenyltetrazolium bromide) in wells containing Batrachochytrium dendrobatidis ( $B d)$. The MTT assay provides a colorimetric measurement of metabolically active cells. A volume of $20 \mu \mathrm{L}$ of $5 \mathrm{mg} / \mathrm{mL}$ MTT added to $100 \mu \mathrm{L}$ of $B d$ culture (purple) produced a greater color change than $10 \mu \mathrm{L}$ (pink). With the addition of $20 \mu \mathrm{L} 5 \mathrm{mg} / \mathrm{mL}$ MTT, the assay was maximized after a 2-4-h incubation (Color figure online).

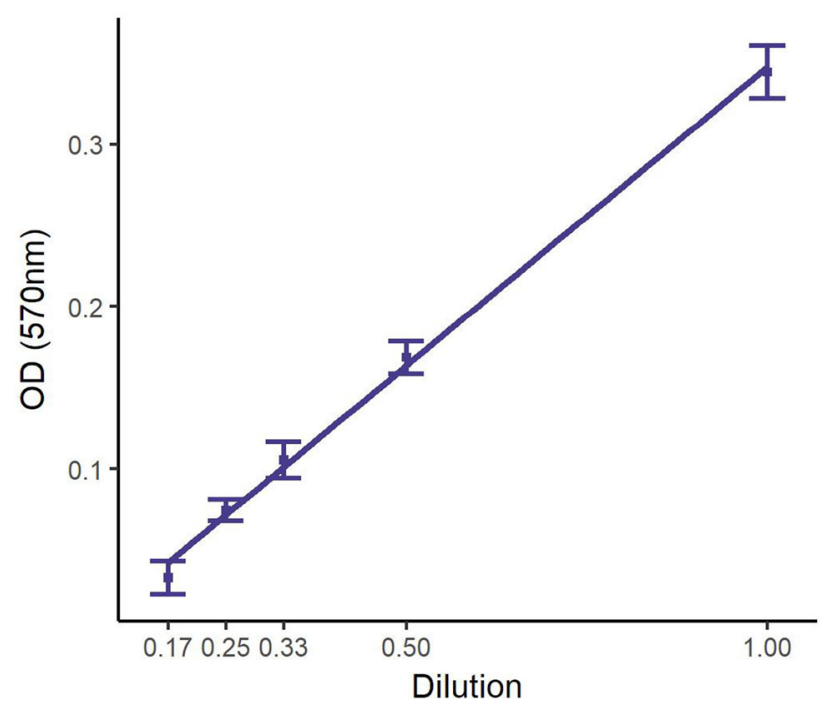

Figure 2. Optical density (OD) measurements in wells of serially diluted Batrachochytrium dendrobatidis $(B d)$. The wells containing $B d$ were incubated with $20 \mu \mathrm{L} 5 \mathrm{mg} / \mathrm{mL}$ MTT for $2 \mathrm{~h}$. OD readings were directly proportional to $B d$ densities.

increased linearly with increasing cell density for live $B d$ cultures assayed with MTT $\left(F_{(1,44)}=604.5, P<0.001\right.$, $\left.R^{2}=0.93\right)$.

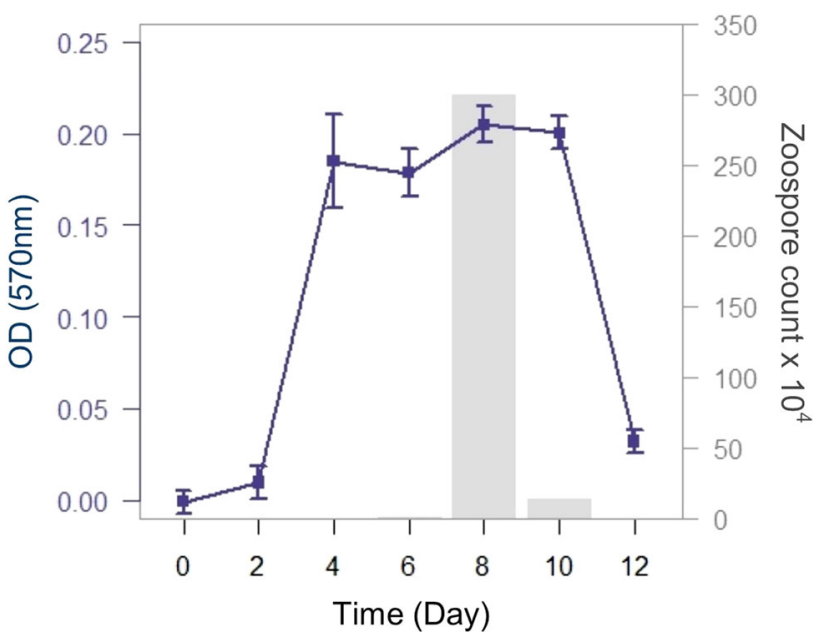

Figure 3. Growth of Batrachochytrium salamandrivorans (Bsal) over time using the MTT assay. Optical density measurements $\left(\mathrm{OD}_{570}\right)$ were collected after incubating Bsal in $20 \mu \mathrm{L} 5 \mathrm{mg} / \mathrm{mL}$ MTT ( $n=12$ randomly selected wells per day). The peak in OD readings coincided with maximum zoospore densities (gray bars) on day 8 .

We found that the MTT assay effectively measures $B d$ and Bsal viability over time. Reduction of MTT by live Bsal zoosporangia increased until peak zoospore release on day 8, after which zoosporangia viability decreased (Fig. 3). $B d$ zoosporangia viability increased through the period of peak zoospore release and plateaued on days 10-12 (Fig. 4). Culture growth as measured by $\mathrm{OD}_{490}$ without the MTT assay also increased over time and reached stationary phase by day 12 . The MTT assay produced a higher colorimetric signal over time than $\mathrm{OD}_{490}$ measurements without MTT (Fig. 4; ANCOVA, $F_{(3108)}=360.4, P<0.001$; assay/day, $t=5.42, P<0.001)$.

Our results suggest that the MTT assay is an effective tool for quantifying $B d$ and $B s a l$ viability over time. Using a 2-h MTT incubation, the MTT assay is an efficient way to collect $B d$ and Bsal viability data during reproductive cycles. This method improves on measurements of $\mathrm{OD}_{490}$ alone because it can quantify growth of a specific life stage and it amplifies the OD signal (Fig. 4). Moreover, this method allows researchers to capture lag, exponential, stationary, and decay phases of pathogen growth (Fig. 3). When paired with measurements of zoospore production, this assay may help resolve other aspects of pathogen growth and reproduction.

The MTT assay will allow investigators to measure pathogen viability under ecologically relevant conditions, which can help improve understanding of pathogen growth in vivo. For example, amphibians contend with changes in ambient temperatures, which likely influences 


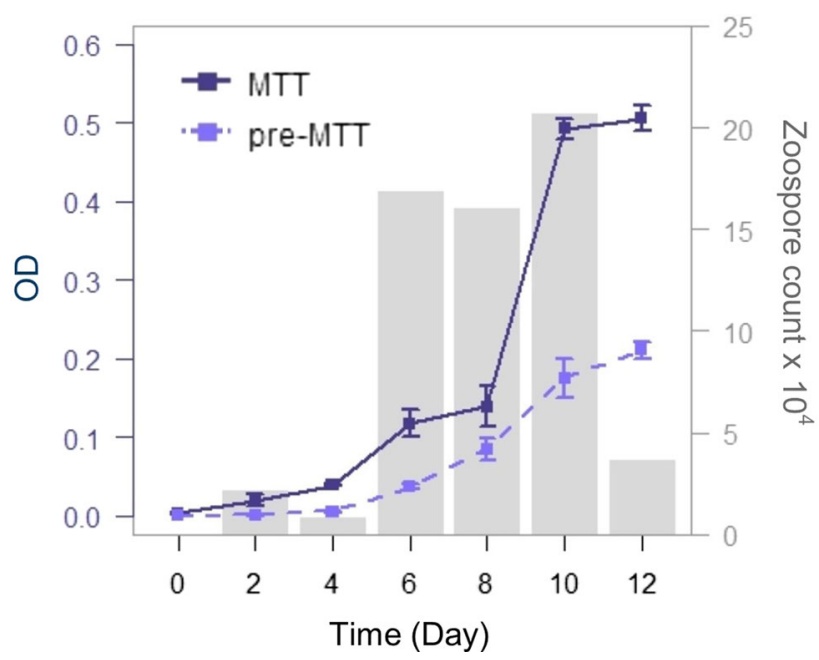

Figure 4. A comparison of optical density (OD) measurements of Batrachochytrium dendrobatidis $(B d)$ over time with and without incubation with MTT. OD measurements with MTT (solid dark blue, read at an optimum wavelength of $570 \mathrm{~nm}, n=8$ randomly selected wells per day) were greater than measurements without MTT (dashed light blue, read at an optimum wavelength of $490 \mathrm{~nm}$ ). Maximum $B d$ growth was evident on days 10-12 and coincided with maximum zoospore densities on day 10 (gray bars) (Color figure online).

pathogen growth (Richards-Zawacki 2009; Rowley and Alford 2013). Using the MTT assay, pathogen growth and viability can be modeled in vitro to assess their responses to dynamic thermal environments (Woodhams et al. 2008; Voyles et al. 2012). In addition, MTT assays could provide an effective method for quantifying $B d$ or Bsal viability in the presence of inhibitory compounds such as antimicrobial peptides produced in frog skin glands, or antifungal metabolites produced by the amphibian skin microbiome (Rollins-Smith et al. 2002, 2006; Harris et al. 2009). Applying the MTT assay to a range of experimental $B d$ and $B s a l$ research questions can help improve our understanding of the ecology of chytridiomycosis.

\section{ACKNOWLEDGEMENTS}

We thank the Research Working Group of the North American Bsal Task Force, Cecelia Ogunro, Carley Barron, Snezna Rogelj, and Sally Pias for insights and support and Frank Pasmans for providing the Bsal isolate. This study was funded by National Science Foundation (IOS-1603808 and DEB-1551488 to JV).

\section{Data Availability}

Datasets are available from the corresponding author upon request.

\section{Compliance with Ethical Standards}

Human and Animal Rights This study did not involve humans or animals.

\section{Open Access}

This article is distributed under the terms of the Creative Commons Attribution 4.0 International License (http://c reativecommons.org/licenses/by/4.0/), which permits unrestricted use, distribution, and reproduction in any medium, provided you give appropriate credit to the original author(s) and the source, provide a link to the Creative Commons license, and indicate if changes were made.

\section{REFERENCES}

Altman FP (1976) Tetrazolium salts and formazans. Progress in Histochemistry and Cytochemistry 9(III):3-51

Berger L, Speare R, Daszak P, Green DE, Cunningham AA, Goggin CL, Slocombe R, Ragan MA, Hyatt AD, McDonald KR, Hines HB (1998) Chytridiomycosis causes amphibian mortality associated with population declines in the rain forests of Australia and Central America. Proceedings of the National Academy of Sciences 95(15):9031-9036

Berger L, Hyatt AD, Speare R, Longcore JE (2005) Life cycle stages of the amphibian chytrid Batrachochytrium dendrobatidis. Diseases of Aquatic Organisms 68(1):51-63

Boyle DG, Hyatt AD, Daszak P, Berger L, Longcore JE, Porter D, Hengstberger SG, Olsen V (2003) Cryo-archiving of Batrachochytrium dendrobatidis and other chytridiomycetes. Diseases of Aquatic Organisms 56(1):59-64

Freimoser FM, Jakob CA, Aebi M, Tuor U (1999) The MTT [3-(4, 5-dimethylthiazol-2-yl)-2, 5-diphenyltetrazolium bromide] assay is a fast and reliable method for colorimetric determination of fungal cell densities. Applied and Environmental Microbiology 65(8):3727-3729

Hansen MB, Nielsen SE, Berg K (1989) Re-examination and further development of a precise and rapid dye method for measuring cell growth/cell kill. Journal of Immunological Methods 119(2):203-210

Harris RN, Brucker RM, Walke JB, Becker MH, Schwantes CR, Flaherty DC, Lam BA, Woodhams DC, Briggs CJ, Vredenburg VT, Minbiole KP (2009) Skin microbes on frogs prevent morbidity and mortality caused by a lethal skin fungus. The ISME Journal 3(7):818 
Levitz SM, Diamond RD (1985) A rapid colorimetric assay of fungal viability with the tetrazolium salt MTT. Journal of Infectious Diseases 152(5):938-945

Liu Y, Peterson DA, Kimura H, Schubert D (1997) Mechanism of cellular 3-(4, 5-dimethylthiazol-2-yl)-2, 5-diphenyltetrazolium bromide (MTT) reduction. Journal of Neurochemistry 69(2):581-593

Longcore JE, Pessier AP, Nichols DK (1999) Batrachochytrium dendrobatidis gen. et sp. nov., a chytrid pathogenic to amphibians. Mycologia 91:219-227

Martel A, Spitzen-vanderSluijs A, Blooi M, Bert W, Ducatelle R, Fisher MC, Woeltjes A, Bosman W, Chiers K, Bossuyt F, Pasmans F (2013) Batrachochytrium salamandrivorans sp. nov. causes lethal chytridiomycosis in amphibians. Proceedings of the National Academy of Sciences 110(38):15325-15329

McMahon TA, Rohr JR (2014) Trypan blue dye is an effective and inexpensive way to determine the viability of Batrachochytrium dendrobatidis Zoospores. EcoHealth 1:4

Mosmann T (1983) Rapid colorimetric assay for cellular growth and survival: application to proliferation and cytotoxicity assays. Journal of Immunological Methods 65(1-2):55-63

Pinheiro J, Bates D, DebRoy S, Sarkar D, R Core Team (2018) nlme: Linear and Nonlinear Mixed Effects Models. R package version 3.1-137. https://CRAN.R-project.org/package= nlme

Piotrowski JS, Annis SL, Longcore JE (2004) Physiology of $\mathrm{Ba}$ trachochytrium dendrobatidis, a chytrid pathogen of amphibians. Mycologia 96(1):9-15

R Core Team (2018) R: A Language and Environment for Statistical Computing, R Foundation for Statistical Computing, Vienna, Austria. https://www.R-project.org/

Richards-Zawacki CL (2009) Thermoregulatory behaviour affects prevalence of chytrid fungal infection in a wild population of Panamanian golden frogs. Proceedings of the Royal Society of London B: Biological Sciences 277:519-528

Rollins-Smith LA, Carey C, Longcore J, Doersam JK, Boutte A, Bruzgal JE, Conlon JM (2002) Activity of antimicrobial skin peptides from ranid frogs against Batrachochytrium dendrobatidis, the chytrid fungus associated with global amphibian declines. Developmental \& Comparative Immunology 26(5):471479

Rollins-Smith LA, Woodhams DC, Reinert LK, Vredenburg VT, Briggs CJ, Nielsen PF, Conlon JM (2006) Antimicrobial peptide defenses of the mountain yellow-legged frog (Rana muscosa). Developmental \& Comparative Immunology 30(9):831-842
Rowley JJ, Alford RA (2013) Hot bodies protect amphibians against chytrid infection in nature. Scientific Reports 3:1515

Skerratt LF, Berger L, Speare R, Cashins S, McDonald KR, Phillott AD, Hines HB, Kenyon N (2007) Spread of chytridiomycosis has caused the rapid global decline and extinction of frogs. EcoHealth 4(2):125

Stegen G, Pasmans F, Schmidt BR, Rouffaer LO, Van Praet S, Schaub M, Canessa S, Laudelout A, Kinet T, Adriaensen C, Haesebrouck F, Bert W, Bossuyt F, Martel A (2017) Drivers of salamander extirpation mediated by Batrachochytrium salamandrivorans. Nature 544(7650):353

Stockell MP, Clulow J, Mahony MJ (2010) Efficacy of SYBR 14/ propidium iodide viability stain for the amphibian chytrid fungus Batrachochytrium dendrobatidis. Diseases of Aquatic Organisms 88:177-181

Van Rooij P, Martel A, Haesebrouck F, Pasmans F (2015) Amphibian chytridiomycosis: a review with focus on fungus-host interactions. Veterinary Research 46(1):137

Voyles J, Young S, Berger L, Campbell C, Voyles WF, Dinudom A, Cook D, Webb R, Alford RA, Skerratt LF, Speare R (2009) Pathogenesis of chytridiomycosis, a cause of catastrophic amphibian declines. Science 326(5952):582-585

Voyles J (2011) Phenotypic profiling of Batrachochytrium dendrobatidis, a lethal fungal pathogen of amphibians. Fungal Ecology 4(3):196-200

Voyles J, Johnson LR, Briggs CJ, Cashins SD, Alford RA, Berger L, Skerratt LF, Speare R, Rosenblum EB (2012) Temperature alters reproductive life history patterns in Batrachochytrium dendrobatidis, a lethal pathogen associated with the global loss of amphibians. Ecology and Evolution 2(9):2241-2249

Voyles J, Johnson LR, Rohr J, Kelly R, Barron C, Miller D, Minster J, Rosenblum EB (2017) Diversity in growth patterns among strains of the lethal fungal pathogen Batrachochytrium dendrobatidis across extended thermal optima. Oecologia 184(2):363-373

Vredenburg VT, Knapp RA, Tunstall TS, Briggs CJ (2010) Dynamics of an emerging disease drive large-scale amphibian population extinctions. Proceedings of the National Academy of Sciences 107(21):9689-9694

Wake DB, Vredenburg VT (2008) Are we in the midst of the sixth mass extinction? A view from the world of amphibians Proceedings of the National Academy of Sciences 105:11466-11473

Woodhams DC, Alford RA, Briggs CJ, Johnson M, Rollins-Smith LA (2008) Life history tradeoffs influence disease in changing climates: strategies of an amphibian pathogen. Ecology 89(6):1627-1639 